\title{
Corporate Social Responsibility Scale Development Proposal
}

\author{
Jeremy Morgan
}

\begin{abstract}
It has been found that social ratings have a positive association with corporate success. Institutional investors are more likely to invest in socially responsible companies (Graves and Waddock 1994; Teoh and Shiu 1990). There is also a positive link between social rating and performance (McGuire et al. 1988; Wokutch and Spenser 1987). Waddock and Graves (1997) have noted that the most serious problem with studying social responsibility in the past has been issues with measurement.

Today, the most widely used measurement of social responsibility is compiled by Kinder, Lydenberg, and Domini (KLD). Based on Ullmann (1985), KLD rates all 500 S\&P companies based on eight attributes. Five of the attributes are focused on stakeholder relationships (Prahalad and Hamel 1994): community relations, employee relations, environmental performance, product characteristics, and treatment of women and minorities. The final three attributes are military contracting, participation in nuclear power, and involvement in South Africa.

Most of this information comes directly from the companies being rated (Waddock and Graves 1997). I believe that the independence of these ratings comes into question. It is generally the role of the investor relations office to generate positive "spin" in favor of the company. While some corporate-controlled data is subject to strict standards (such as annual financial reports), most of the data obtained by KLD is not.

I believe that KLD, or anyone seeking to rate companies on socially responsible performance, must find a more independent source of data. I propose that because five of the eight important attributes that make up the construct of social responsibility are stakeholders (Ullmann 1985), it is those very stakeholders that should be surveyed. It is the relationships with those groups (customers, employees, women, and minorities) that represent a large part of social responsibility.
\end{abstract}

\footnotetext{
J. Morgan ( $ه)$

University of Texas at Arlington, Arlington, TX 76019, USA

e-mail: Jeremy.morgan10@mavs.uta.edu
} 